\title{
Legitimidade Recursal do Amicus Curiae
}

Bethsaida de Sá Barreto Diaz Gino ${ }^{1}$; Érika Samara Santana Faustino Silva² ; Társis da Costa Carneiro Pontes Dantas ${ }^{3}$

\begin{abstract}
Resumo: Ao passo que a ciência processual evolui e novas figuras processuais surgem torna-se essencial ao regular desenvolvimento do processo de controle de constitucionalidade abstrato a figura do amicus curiae. Esse instituto tem sido alvo de divergências doutrinárias quanto à sua natureza jurídica e poderes de atuação no processo, em especial quanto à sua legitimidade recursal. O presente trabalho faz um apanhado geral acerca das principais correntes que definem sua natureza jurídica e tem como principal objetivo analisar a interferência essa definição na limitação dos poderes de atuação daquele, identificando o melhor posicionamento a ser seguido. A discussão gira em torno do interesse jurídico que o amicus tem nas causas em que pretende ingressar. Quem defende que o amicus curiae tem natureza jurídica de auxiliar do juízo, baseia-se na própria função por ele desenvolvida, pois seu único objetivo é levar a conhecimento do juízo definições e conceitos técnicos em matéria que tenha vasta e reconhecida experiência. Sendo auxiliar do juízo, sua função se esgota ao levar ao processo sua experiência acerca da matéria discutida. Em contrapartida, há corrente defendo que amicus curiae tem natureza de terceiro interessado. Defini-lo como auxiliar do juízo nos parece a melhor solução, permitindo a melhor delimitação deste dentro do processo, fazendo com que sua legitimidade recursal recaia apenas sobre a decisão que indefere seu ingresso na lide.
\end{abstract}

Palavras-Chave: Amicus Curiae, natureza jurídica, legitimidade recursal.

\section{Legitimacy of Appeals Amicus Curiae}

Abstract: While the procedural science evolves and new procedural figures appear it becomes essential to regular development of abstract constitutionality control process, the figure of amicus curiae. This institute has been the subject of doctrinal disagreement about its legal nature and acting powers in the process, in particular about its appeal legitimacy. This paper is an overview about the main currents that define its legal nature and its main objective is to analyze the interference that definition in limiting the performance of powers of that, identifying the best position to be followed. The discussion revolves around the legal interest that the amicus has in cases where he wants to join. Who argues that the amicus curiae has legal nature of assistant of the court,he is based upon the function itself for him developed because his only purpose is to take to the knowledge of the court definitions and technical concepts on matter which he has extensive and recognized experience. As auxiliary of the court, his function is exhausted by taking to process his experience about the discussed matter. In contrast, there is current arguing that amicus curiae has third interested nature. Set him like assistant of the court seems to be the best solution, allowing better delimitation of him within the process, making his appeal legitimacy falls only on the decision that rejects his entry into the conflict.

Keywords: Amicus Curiae, legal nature, appellate legitimacy.

\footnotetext{
${ }^{1}$ Advogada pela Universidade Regional do Cariri - URCA, Pós-graduada em Direito Previdenciário e Trabalhista pela Universidade Regional do Cariri - URCA, Pós-graduada em Direito Processual Civil pela Universidade Regional do Cariri - URCA, Advogada, Sócia Proprietária do Escritório: Dantas \& Gino Advocacia, Primeira Vice-Presidente da Comissão de Direito Imobiliário da Ordem dos advogados do Brasil, Subseccional Juazeiro do Norte, Ceará. E-mail: bethsaidagino@hotmail.com;

${ }^{2}$ Advogada pela Universidade Regional do Cariri (2011) e especialista em Direito Processual Civil. Atualmente é advogada na área cível e Técnica do Seguro Social do Instituto Nacional do Seguro Social. Encontra-se em processo de especialização em Direito Constitucional. Tem experiência na área de Direito, com ênfase em Direito Previdenciário.

${ }_{3}^{3}$ Advogado. pela Faculdade Paraíso do Ceará - FAP, Pós-graduando em Direito Trabalho e Previdenciário pela Faculdade Paraíso do Ceará FAP, Advogado, Sócio do Escritório de Advocacia: Dantas, Gino \& Advogados Associados
} 
Id on Line Revista Multidisciplinar e de Psicoloqia

Id on Line Multidisciplinary Journal and Psycology

\section{Introdução}

O instituto do amicus curiae, figura auxiliar do processo, é tratado como terceiro interessado em levar a conhecimento do juízo fatos e conceitos técnicos a respeito do ponto central de discussão da lide, a fim de influenciar o julgamento e prolação da sentença, permitindo que o magistrado tenha visão geral e consistente de todos os aspectos e sujeitos que venham a ser afetados com a decisão no caso concreto.

De origem remota, com primeira forma de expressão na Roma antiga, o instituto passou por diversas reconstruções até ser positivado no Direito Brasileiro, como o conhecemos atualmente.

É pacífica a função do amicus curiae, entendida como fonte de informação do magistrado. A polêmica que circunda o tema está direcionada à função e limites de atuação deste sujeito processual. Uma vez que ainda a doutrina ainda debate a natureza jurídica do amicus curiae, visto que a definição de sua natureza como parte, terceiro interessado ou auxiliar do juízo, traçará os limites de sua atuação.

A importância do estudo do instituto está evidenciada na conferência de maior legitimidade às decisões judiciais, porquanto dará ao juízo conhecimentos específicos da matéria tratada, o que não ocorreria sem a interferência do amicus curiae. Neste diapasão, a caracterização da natureza jurídica definirá quando e como pode atuar, seja para ingressar em lides que tramitem em primeira instância, seja para apresentar recursos quanto a decisão proferida. É a definição de seu interesse de agir que levará a sua acomodação no cenário jurídico brasileiro. De um lado há interesse em tornar as decisões judiciais cada vez mais acertadas, de outro há o fato inegável de que a atuação do amicus influenciará a decisão em favor de uma das partes. Assim temos o seu interesse como ponto de partida para definição de sua natureza jurídica.

Diante do exposto, não se pode ignorar a pertinência do estudo da natureza jurídica e poderes processuais do amicus curiae, porquanto cabe a ele a função de levar ao conhecimento do juízo conceitos que de outra forma não comporiam o processo, tornando este mais democrático e transparente, atendendo a função de levar justiça e resolver da melhor forma os conflitos suscitados.

\section{Objetivo e Metodologia}

A presente pesquisa terá por objetivo analisar as correntes doutrinárias e respectivas definições da natureza jurídica do amicus, utilizando a ponderação do real interesse deste como meio de verificar onde e como deve ser alocado no processo.

Para tanto esta pesquisa se desenvolveu através de estudo bibliográfico, tendo como principais 
Id on Line Revista Multidisciplinar e de Psicoloqia

Id on Line Multidisciplinary Journal and Psycology

fontes livros doutrinários, artigos científicos, jurisprudências, bem como análise da legislação processual civil e da Constituição Federal. Sempre que necessário foi utilizado o método dedutivo de abordagem e a exegese jurídica para se chegar as principais conclusões.

\section{Referencial Teórico e Desenvolvimento}

A tarefa de definição do amicus curiae não se mostra das mais fáceis na doutrina pátria, seja pela sua recente aparição no cenário jurídico brasileiro, seja pela falta de consenso em relação à definição de sua natureza jurídica, dada as diversas situações em que pode figurar no processo. Essa discussão doutrinária entre definição e natureza jurídica vem sendo desempenhada pela doutrina brasileira de forma bastante louvável, com vastas produções acadêmicas e jurisprudenciais.

O instituto processual amicus curiae é recente, tanto no Brasil quanto no Direito Comparado, o que suscita diversas divergências doutrinárias acerca de sua definição. Sua função é informar aos magistrados sobre a matéria subjudice, fornecendo-lhes elementos que possibilitem um melhor julgamento. A primeira aparição na legislação brasileira data de 07 de dezembro de 1976, quando da publicação da Lei 6.835/76 que trata da Comissão de Valores Mobiliários. No entanto, foi a Lei 9.868/1999 que trouxe o amigo da corte com maior relevância para o cenário jurídico pátrio, pois trata de intervenção de um terceiro no processo de controle concentrado de constitucionalidade junto ao Supremo Tribunal Federal. Atualmente, em recente inovação da dogmática processual, o novo Código de Processo Civil (Lei nº 13.105/2015) passou a prever a atuação do amicus.

Pode-se dizer que a relação processual é formada de triangularmente pelas partes e pelo magistrado, e encontra-se estabilizada após a citação do réu. Desta forma, qualquer pessoa que ingresse na relação após a triangulação será considerada terceiro de forma geral e não deterá a qualidade de parte. "O conceito de parte deve restringir-se àquele que participa (ao menos potencialmente) do processo com parcialidade. [...] Parte é que postula ou contra quem se postula ao longo do processo, e que age, assim, passionalmente” (DIDIER JR., 2006, p. 294).

Desta forma, para ser parte ou se está inicialmente ou no polo passivo ou ativo da relação processual, quando o processo se estabiliza e se define quem e contra quem se está demandando, ou de forma tardia, quando ocorre algum dos fenômenos da substituição processual.

Já o terceiro é aquele que ingressa no processo após a estabilização da demanda, seja por ter interesse em sentença favorável a uma das partes, seja por existirem direitos seus sendo discutidos em juízo sem a sua presença. O conceito de intervenção de terceiro, como fato jurídico processual, envolve todos os sujeitos estranhos à relação processual que nela ingressam, recebendo o processo no estado em que se encontra, vinculando-se à parte a que presta assistência ou assumindo seu lugar. A 
Id on Line Revista Multidisciplinar e de Psicoloqia

Id on Line Multidisciplinary Journal and Psycology

figura do terceiro no processo ocorre para fins de economia processual, em respeito à celeridade da prestação jurisdicional, para que futuramente não seja criado novo processo para se rediscutir a demanda, ainda que sob outro enfoque. Assim, o terceiro ingressa no processo para que a demanda, e todos os efeitos que afetam aqueles que não sejam partes no processo, sejam discutidos em um só momento, garantindo que a causa seja explorada da melhor forma possível. Garante ainda o princípio da boa-fé processual, pois o devido processo legal pressupõe lealdade entre as partes, isto é, sem que existam comportamentos indevidos ou ações ilícitas com o intuito de prejudicar o adversário.

Dito isto, cumpre ressaltar que a definição do que seja parte e do que seja terceiro é de fundamental importância para definição da natureza jurídica e conceito do amicus curiae, somado ao estudo de sua origem histórica. Podemos dizer ainda que a definição da natureza jurídica envolve analisar os pontos de afinidade entre um instituto e outro, determinando sua essência e alocando-o em um grupo de figuras já existentes no Direito.

\section{Definição e Natureza Jurídica}

O amicus curiae, ou amigo da corte, é uma espécie de auxiliar do juízo, chamado a participar da lide quando o magistrado necessita de maior conhecimento técnico para apreciação da matéria. Tem a função de levar ao conhecimento do magistrado dados sobre matérias técnicas fornecendo apoio e colaborando na elaboração de sentenças mais profundas com conceitos, definições ou informações em matéria na qual tenha profundo e reconhecido conhecimento. Desta forma tem a função de acrescentar ao conhecimento do juiz novos elementos que contribuam para uma decisão mais próxima ao senso de justiça e aspirações da sociedade. Para Didier Jr (2006, p. 351), o amicus é verdadeiro auxiliar do juízo.

O amici faz parte do quadro de sujeitos processuais com função de auxílio a funções técnicojurídicas. Por auxiliar na hermenêutica e não servir de instrumento de prova, se distingue dos peritos. A ele não são dados honorários, sendo comum que compareça ao processo por solicitação do magistrado.

Também não pode ser atribuída a ele a função custus legis própria do Ministério Público, pois sua função é unicamente trazer ao processo conhecimentos técnico-jurídicos especializados como forma de aprimorar a prestação da tutela jurisdicional. Não cabe a ele a função de fiscal da lei ou de participação obrigatória em causas de direito indisponível. Já a condição de estar no processo fornecendo elementos de interpretação e atualização para o magistrado também não o enquadra como terceiro.

Há, ainda, outros elementos de distinção, como a possibilidade de intervir no processo por 
Id on Line Revista Multidisciplinar e de Psicoloqia

Id on Line Multidisciplinary Journal and Psycology

petição própria, não estar sujeito à arguição de impedimento ou suspeição, não havendo falar em imparcialidade, e não lhe são dados prazos para entrega de memoriais.

Quanto à natureza jurídica, pode-se afirmar que a doutrina contemporânea traz três principais correntes, sendo que todas criam a possibilidade de manifestação de um órgão ou entidade em auxílio ao magistrado, conforme nos ensina Moraes (2011, p. 3).

Para os que consideram que o amicus curiae é assistente qualificado, prepondera a noção de que somente pode intervir na lide aquele que demonstre interesse jurídico na demanda, seja por ter direito seu discutido, seja por ter interesse jurídico em sentença favorável a uma das partes. O interesse jurídico se manifesta quando a decisão desfavorável à parte que é assistida possa vir a causar prejuízos na esfera de direitos de quem assiste, sendo que o interesse meramente econômico não autoriza assistência. Para tal corrente, o interesse jurídico na resolução do conflito não pode ser dispensado no exame da admissibilidade de quem postula ingressar na demanda como amicus curiae, pois os elementos que este trará ao processo devem incluir a esfera de convencimento do magistrado de forma imparcial. Para Didier Jr. (2006, p. 301) a assistência é modalidade de intervenção de terceiros ad coadjuvandum.

Desta feita, a assistência é tratada pela doutrina de forma unânime como espécie de intervenção. Tal posicionamento foi contemplado pelo Novo Codex, que passou a prever a assistência no capítulo da intervenção de terceiros, sendo que o código anterior a tratava em capítulo diverso. Assim, entendemos não caber acolhimento a esta primeira corrente.

A corrente doutrinária que defende o amicus curiae como uma espécie de intervenção de terceiros, acolhe que a admissão do amici deve observar requisitos objetivos, isto é, sem que haja necessária demonstração de interesse jurídico, bastando tão-somente a existência de interesse econômico. Para tal corrente, toda vez que lei nova vier a trazer ao ordenamento jurídico a previsão de intervenção do amicus curiae estará, na verdade, trazendo forma diferenciada de intervenção de terceiros. Em contraponto a esta corrente, encontramos na lição de Binenbojn (2004, p. 85), que nos ensina ainda que a objetividade do processo de controle de constitucionalidade, como será visto mais adiante, é que veda a intervenção de terceiros.

A intervenção de terceiros tem o propósito de economia processual, evitando a repetição de atos processuais e a harmonização dos julgados, evitando decisões contraditórias. Para Neves (2011, p. 207), é natural que o terceiro, ao ser admitido no processo, deixa de sê-lo e torna-se parte, seja parte na demanda ou parte no processo. Entendemos que o amicus curiae não se encaixa na conceituação de parte, uma vez que seu interesse em participar do processo não é prima facie uma decisão favorável a si ou à classe que representa, mas sim levar a conhecimento "a melhor solução possível do processo por meio do maior conhecimento da matéria e dos reflexos no plano prático da decisão" (NEVES, 
Id on Line Revista Multidisciplinar e de Psicoloqia

Id on Line Multidisciplinary Journal and Psycology

2011, p. 209). Assim, embora o novo Codex tenha positivado o instituto no capítulo pertinente a intervenção de terceiros, entendemos que estaria melhor alocado na geografia do código se tivesse tratamento em capítulo próprio.

A terceira corrente admite que a natureza jurídica do amici seja de auxiliar do juízo, sendo a corrente com menos adeptos na doutrina brasileira. De acordo com tal corrente, o colaborador é neutro no processo, apesar de não estar sujeito a causas de suspeição e impedimento, deve ser imparcial e ter como único interesse levar a juízo fatos, argumentos e conceitos que contribuam para a formação da melhor solução aplicável ao caso concreto.

Assim, o auxiliar não está no processo para defender interesse próprio, mas sim para apresentar questões de fato e de direito pertinentes à controvérsia. Sendo este o caso do Amicus Curie, que está no processo para dar evidência às matérias de interesse da coletividade geral.

De acordo com o processualista Didier Jr (2006, p. 352) a própria nomenclatura revela que estamos diante de um auxiliar do juízo e não de um postulante, sujeito parcial do processo.

Neste ponto, há concordância com a corrente defendida pelo processualista Fredie Didier Jr. O amicus curiae não deve ser considerado terceiro interessado, uma vez que não há necessidade de que demonstre interesse processual no litígio em si, estando em juízo apenas como figura assessória de auxílio ao órgão julgador. Não deve ser considerado assistente por ser esta espécie intervenção de terceiros ad coadjuvandum, e considerando ser a intervenção vedada no art. $7^{\circ}$, caput da Lei 9.868/99. Sua função é exatamente a de trazer novos elementos que possam auxiliar na formação da convicção do magistrado por uma ou outra decisão, trazendo uma maior legitimidade às decisões judiciais por abrir os debates à sociedade, principalmente em sede de controle de constitucionalidade abstrato.

Essa é a posição adotada também pelo ex-Ministro do Superior Tribunal de Justiça e professor Athos Gusmão Carneiro. Cabe acrescentar, a título de informação do cenário jurídico brasileiro que a jurisprudência pátria, em especial o STF, vem proferindo entendimentos no sentido de que o amicus curiae é um singular assistente, pois opina em favor de uma das partes, já que de seu parecer surge o êxito de uma delas. Por óbvio, os argumentos trazidos pelo amicus auxiliarão uma das partes, já que interferem na decisão do magistrado, no entanto, como só há necessidade de demonstrar pertinência temática e não interesse jurídico, tal conclusão lógica não afeta a qualidade de assistente a ele conferida.

Oportuno citar decisão do Superior Tribunal de Justiça no Recurso Especial 677.585 - RS (2004/0126889-8), Primeira Turma, Rel. Min. Luis Fux.

RECURSO ESPECIAL EM AGRAVO DE INSTRUMENTO. TUTELA ANTECIPADA. TRANSPORTADORAS DE VEÍCULOS. "CEGONHEIROS". INDÍCIOS DE ABUSO DE PODER ECONÔMICO E FORMAÇÃO DE CARTÉIS.

$[\ldots]$ 
19. É cediço no Eg. STJ que "em ação proposta pelo Ministério Público Federal, órgão da União, somente a Justiça Federal está constitucionalmente habilitada a proferir sentença que vincule tal órgão" (CC 40.534, Rel. Min. Teori Albino Zavascki, DJ de 17/05/04). Ademais, o amicus curiae opina em favor de uma das partes, o que o torna um singular assistente, porque de seu parecer exsurge o êxito de uma das partes, por isso a lei o cognomina de assistente. É assistente secundum eventum litis.

Por assistente secundum eventum litis, entende-se aquele que se porta segundo o resultado do processo. Isto é, embora venha a ser admitido no processo com o objetivo de auxiliar do juízo, ao ser prolatada a sentença, sua interferência beneficiará uma das partes, podendo-se definir de quem será assistente.

Discordamos desse posicionamento tendo em vista que, de fato, o auxiliar, qualquer que seja ele, influenciará para que a decisão ocorra em favor de uma das partes. Porém a cognição lógica que o magistrado efetua ao prolatar a sentença não tem o condão de descaracterizar a natureza do auxiliar.

\section{Controle de Constitucionalidade Abstrato e o Amicus Curiae}

O controle abstrato tem por função retirar do ordenamento jurídico norma que tenha sido elaborada ao arrepio da Constituição, em observância ao princípio da supremacia das normas constitucionais. Tal mecanismo é possível por tratar-se, a Constituição Federal de 1988, de constituição rígida, isto é, exige mecanismo elaborado e solene de alteração, não admitindo mudança de seu texto por ato infraconstitucional, encontrando-se no topo da hierarquia normativa.

Os processos de controle de constitucionalidade interessam a toda sociedade, uma vez que ela é a destinatária da norma, e é dela que emana o poder constituinte que está sendo violado, conforme o Art. $1^{\circ}$, Parágrafo único da Constituição Federal: "Art. $1^{\circ}$ [...] Parágrafo único. Todo poder emana do povo, que o exerce por meio de representantes eleitos ou diretamente, nos termos desta Constituição".

Cabe ao STF, a guarda da Constituição, sendo responsável pela proteção desta e fiscalização da validade das normas. A competência originária que lhe é atribuída significa dizer que o "Supremo exerce sua função jurisdicional em nível de primeira instância, tomando conhecimento da ação, incidente ou pedido diretamente" (MELO et al., 2010, p. 633). Neste caso as ações apreciadas pelo STF se esgotam nele mesmo, sendo considerada instância única, por não existir órgão de hierarquia jurisdicional superior.

O procedimento pelo qual deve tramitar a ação direta de inconstitucionalidade vem regulado pela Lei 9.868/1999, que prevê trâmite, prazos e requisitos de admissibilidade das petições. Como já dito, seu art. $7^{\circ}$ veda a intervenção de terceiros, uma vez que se trata de controle abstrato no qual não 
Id on Line Revista Multidisciplinar e de Psicoloqia

Id on Line Multidisciplinary Journal and Psycology

existem partes no sentido próprio do termo, mas sim legitimados a propor a ação, sendo que para alguns deles será exigida pertinência temática. Nos dizeres de Bisch (2010, p.107), existe requerimento neste procedimento, mas não propriamente réu ou requerido. Conforme nos ensina Binenbojn (2004, p. 86) o controle é realizado através de um processo objetivo. O processo de controle abstrato da constitucionalidade não envolve pessoas ou interesses concretos, atendo-se à verificação, em tese, da compatibilidade de uma norma determinada com outra que lhe é hierarquicamente superior. Por isso tal processo é considerado objetivo, pois envolve situações jurídicas que se destinam à guarda da Constituição.

Trata-se aqui de processo objetivo, onde não são discutidas relações jurídicas subjetivas e não há aplicação da decisão de forma direta a casos concretos, sendo esta a posição adotada pelo STF no julgamento da Ação Declaratória de Inconstitucionalidade 4.140/GO.

É oportuno acrescentar outro julgado do STF, no qual o relator Ministro Celso de Mello esclarece o instituto da oposição como um dos pressupostos para a vedação de terceiros no controle abstrato. Na ADI 1.350 o STF define que a oposição deve restringir-se ao plano exclusivo dos processos subjetivos.

Tal vedação foi anteriormente prevista no regimento interno do Supremo Tribunal Federal publicado em 27 de outubro de 1980, quando em seu art. 169, § $2^{\circ}$, prevê que o Procurador Geral da República poderá submeter ao Tribunal, mediante representação, o exame de lei ou ato normativo para que seja declarada sua inconstitucionalidade, proibindo assistência a qualquer das partes.

Também o art. $9^{\circ}, \S 1^{\circ}$ da Lei $9.868 / 99$ prevê que em caso de necessidade de esclarecimento de matéria ou circunstância de fato ou de notória insuficiência das informações poderá o relator ouvir depoimento de pessoas com experiência e autoridade na matéria. A lei 9.882/99, que trata do processo e julgamento da arguição de descumprimento de preceito fundamental, nos termos do $\S 1^{\circ}$ do art. 102 da Constituição Federal, traz a mesma previsão em seu art. $6^{\circ}, \S \S 1^{\circ}$ e $2^{\circ}$.

Bisch (2010, p. 104) nos ensina que as influências de Peter Härbele com sua sociedade aberta dos intérpretes da Constituição foi de grande relevância para a admissão do amicus curiae no processo civil brasileiro, em sede de controle de constitucionalidade, pois sugeria a incorporação das ciências sociais e de métodos de interpretação voltados ao atendimento do interesse público. Na visão de Peter Härbele a hermenêutica constitucional envolve todos os órgãos estatais e sugere a participação de toda a sociedade no processo como peritos ou especialistas, a fim de que este seja aprimorado e democratizado.

Assim, em estudo às Leis 9.868/99 e 9.882/99 vemos que o legislador pátrio ampliou o debate em torno da inconstitucionalidade das leis justamente para que o processo se tornasse cada vez mais democrático e as decisões fossem aprimoradas ao máximo, a fim de evitar decisões equivocadas por 
Id on Line Revista Multidisciplinar e de Psicoloqia

Id on Line Multidisciplinary Journal and Psycology

desconhecimento de matérias técnicas não afetas à ciência jurídica. O STF já se posicionou de forma concordante a participação do amicus curiae no processo objetivo de controle normativo abstrato como fator de legitimação social das decisões da Suprema Corte com a finalidade de pluralizar o debate constitucional. (BRASIL, Supremo Tribunal Federal, ADI 3.889/RO, Relator Ministro Joaquim Barbosa).

Neste ponto é importante anotar que as ações declaratórias de constitucionalidade, na opinião de Lenza (2009, p. 232), não admitem intervenção do amicus curiae, uma vez que o Art. 18 , § $2^{\circ}$ da Lei que trata da matéria, que continha a mesma redação do art. $7^{\circ}, \S 2^{\circ}$, foi vetado. Bueno (2008, p. 176), por sua vez, sustenta que embora a lei silencie a respeito da presença do amicus no processo de ADC, tal fato não deve ser óbice a sua admissibilidade para exercer as funções próprias do amici: “[...] Para a ação declaratória de constitucionalidade, a Lei 9.868/99 preservou a possibilidade de o relator instruir o feito na linha do que os arts. $6^{\circ}, 8^{\circ}$ e $9^{\circ}$ expressamente reservam para a ação direta de inconstitucionalidade". (BUENO, 2008, p.176-177)

Concordamos com o posicionamento de Bueno (2008), uma vez que a presença do amicus curiae nos processos de controle tem a função de democratizar o debate em torno do controle de constitucionalidade e considerando que o Art. $20, \S 1^{\circ}$ da Lei $9.868 / 99$ traz permissão para que o relator, caso haja necessidade de esclarecimentos da matéria de fato ou de notória importância, ouça depoimentos de pessoas com experiência e autoridade na matéria. As próprias razões do veto ao $\S 2^{\circ}$ do Art. 18, através da Mensagem n 1.674 de 10 de novembro de 1999, trazem a ressalva de que resta assegurada a possibilidade de o Supremo Tribunal Federal, por meio de interpretação sistemática, admitir no processo da ação declaratória a abertura processual prevista para a ação direta no $\S 2^{\circ}$ do art. $7^{\circ}$

Para admissão do amicus curiae no processo de controle de constitucionalidade se faz necessário que dois requisitos sejam atendidos, quais sejam, relevância da matéria e representatividade do postulante.

A relevância da matéria é relacionada ao próprio objeto da ação e na forma do $\S 2^{\circ}$ do Art. $7^{\circ}$ da Lei 9868/99 deve ser necessário que ingressem nos autos novos elementos que venham a auxiliar de uma ou outra maneira a fundamentação e decisão prolatada na sentença. É relevante a matéria que guarde correspondência coerente com o objeto tratado pela norma que seja objeto do controle.

A representatividade do postulante deve ser observada em paralelo com os legitimados para propor ADI conforme Art. 103 da $\mathrm{CF} / 88$. O citado artigo do texto constitucional traz, conforme orientação do STF, legitimados universais e especiais para propositura das ações de controle de constitucionalidade, sendo que a diferença entre eles é que o último deve demonstrar interesse específico ou uma relação de pertinência temática. A pertinência temática deve existir entra a função 
Id on Line Revista Multidisciplinar e de Psicoloqia

Id on Line Multidisciplinary Journal and Psycology

exercida pela pessoa ou órgão, ou ainda entre as finalidades da entidade, e a matéria tratada pelo ato estatal que se pretende impugnar (MELO et al., 2010, p. 657). Não é sem razão que o Supremo fez tal distinção, já que não seria lógico que uma entidade ou conselho de classe viesse a ingressar em processo totalmente alheio às suas atribuições que não fosse interferir de qualquer modo nas relações de seus representados. O que se pretende é preservar a celeridade processual.

Conforme ensina NEVES (2011, p. 211) o interesse do amicus curiae é institucional compreendido na possibilidade de concreta de contribuir com a qualidade da decisão a ser prolatada, uma vez que deve ter grande experiência na área a qual matéria debatida pertence.

O momento para que o amicus entre no processo é quando chamado pelo relator nos termos do Art. $7^{\circ}, \S 2^{\circ}$ da Lei $9.868 / 99$, ocorre que tal texto normativo é silente não trazendo o momento, dentro do processo em andamento, em que o relator pode requerer tal assistência. Essa lacuna causa grande controvérsia doutrinária acerca de quando seria esse momento.

O STF já havia se posicionado, na ADI 2.937/DF, de Relatoria do Ministro. Cezar Peluso, no sentido de que o momento em que deveria o amicus curiae ingressar no processo seria durante o prazo de resposta ou prestação de informações da autoridade que emanou o ato, chegando-se a falar em preclusão consumativa. No entanto, tal posicionamento não prevaleceu, uma vez que a participação amicus pode ser considerada ato de instrução do processo, já que ele trará novos elementos para a formação de convicção e que se trata, na respeitável opinião dos Tribunais Superiores, de espécie de assistência ao qual deve ser aplicado o Art. 954 do Código de Processo Civil. Assim houve novo posicionamento, no sentido de que o amicus pode se manifestar durante todo o processo até a inclusão em pauta para julgamento, quando então o processo já estaria maduro o suficiente para os debates, conforme ADI 2.238/DF, Rel. Min. Ilmar Galvão.

Bueno (2008, p. 165) sugere que não se pode excluir a manifestação de amicus curiae durante o julgamento, desde que feito a pedido de um dos julgadores e permitido que autor e réu se manifestem a respeito do novo elemento de conviç̧ão em respeito a princípio do contraditório.

A admissão ou não do amicus curiae, nos ensinamentos de Lenza (2009, p. 229), será decidida pelo relator, que verificará o preenchimento dos requisitos e a conveniência e oportunidade da manifestação. O doutrinador destaca que mesmo admitido pelo relator, o Tribunal poderá deixar de referendá-lo, afastando sua intervenção.

Ao amicus curiae são concedidos poderes de se manifestar por escrito conforme Art. $7^{\circ}, \S 2^{\circ}$ da Lei 9.868/99. No entanto, já foi consolidada no Supremo a possibilidade de manifestação oral através de julgados como a ADPF 46/DF e ADI 2.777/SP e Art. 131, § $3^{\circ}$ do Regimento Interno do STF, sendo que este último prevê um prazo de 30 minutos para a exposição. A sustentação oral trará a última oportunidade que o amicus curiae tem de levar a conhecimento dos magistrados sua colaboração 
Id on Line Revista Multidisciplinar e de Psicoloqia

Id on Line Multidisciplinary Journal and Psycology

acerca da matéria discutida no processo.

Com relação à manifestação oral, não há maiores questionamentos. A Lei 9.868/99 que regulamenta a matéria, em seu art. $7^{\circ}$, já traz essa faculdade, que já vinha sendo admitida antes do advento deste diploma pelo STF. A sustentação oral também vem sendo admitida pelo Supremo, embora não conste do texto normativo, como ocorreu na ADPF 46/DF e ADI 2.777/SP. Esta prerrogativa se mostra de fundamental importância na atuação do amicus por contribuir de forma contundente para a formação da conviç̧ão do magistrado, em especial daqueles que não tiveram um maior contanto com o processo.

Nesta linha de argumentação há doutrina que defende que a sustentação oral serve ao esclarecimento dos magistrados e o julgamento colegiado caracteriza-se pelos debates orais. Se o amicus curiae é um fator de aprimoramento da tutela jurisdicional, não há sentido em impor-lhe proibição de que sua manifestação se dê pela via falada e pela via escrita (DIDIER JR, 2006, p. 356)

Embora o diploma normativo que disciplina o processo de controle de constitucionalidade nas ações declaratórias de inconstitucionalidade seja silente, o Supremo Tribunal Federal acresceu o parágrafo único ao art. 131 de seu Regimento Interno, em 30 de março de 2004, facultando a sustentação oral que severa ser feita após a leitura do relatório e antes de proferido os votos dos ministros.

Para Dider Jr. (2006, p. 354), não havendo previsão legal a respeito da forma de realização do ato processual, este pode ser efetivado de qualquer forma (oral ou escrita), desde que atinja a finalidade, que no caso em tela é a de ajudar o tribunal no julgamento. Deve ser aplicada a regra do art. 188 do Código de Processo Civil, segundo o qual os atos e termos processuais não dependem de forma determinada senão quando a lei expressamente exigir, reputando-se válidos os que, realizados de outro modo, lhe preencherem a finalidade essencial.

\section{Legitimidade Recursal do Amicus Curiae nos Processos de Controle de Constitucionalidade Abstrato}

O amicus curiae comparece ao processo de controle de constitucionalidade com pessoa experiente ou com autoridade na matéria em caso de necessidade de esclarecimentos de circunstâncias de fato ou de notória insuficiência de informações existentes nos autos.

Por se tratar de processo objetivo que discute a regularidade constitucional da norma objeto da ação em tese, não há que se falar em partes no sentido próprio da palavra, sendo inclusive vedada a intervenção de terceiros. Tendo em vista exatamente a ausência de partes a serem afetadas e proibição de intervenção de terceiros pelo Art. $7^{\circ}$, caput da Lei 9.868/99, que o amicus curiae é considerado 
Id on Line Revista Multidisciplinar e de Psicoloqia

Id on Line Multidisciplinary Journal and Psycology

auxiliar do juízo.

Sua natureza jurídica de auxiliar é sustentada por Didier Jr (2006) ao considerar que o amicus curiae auxiliará na instrução do processo e não tem o condão de ser meio de prova para uma ou outra parte. É claro que seus memorais auxiliarão para a formação da convicção quanto à constitucionalidade ou não da lei e, por conseguinte, será útil a uma ou outra parte, mas este é efeito secundário de sua atuação. A função precípua é trazer aos Ministros esclarecimentos que possam fomentar o debate no Tribunal do Pleno.

Apesar de possuir amplos poderes processuais, inclusive com a possibilidade de sustentação oral na forma do parágrafo único do Art. 131 do Regimento Interno do STF, o mesmo autor entende que não há para ele legitimidade recursal (DIDIER, 2006, p. 355). No mesmo sentido o Lenza (2009, p. 235) diz que o amicus curiae não pode interpor recurso por se tratar de estranho à relação processual, não havendo falar em possibilidade de discussão por ele da matéria objeto de análise no processo objetivo perante o STF.

Cumpre ressaltar que o tema legitimidade recursal do amicus curiae ainda é mola propulsora de debates doutrinários. Bueno (2008, p. 171-175), apesar de afirmar que a questão se encontra apequenada, visto que o único recurso de mérito cabível é o embargo, é categórico ao dizer que entende ser lícito ao amici apresentar recurso da decisão final que julga a ação direita de inconstitucionalidade ou de qualquer que possa interferir concretamente nos interesse que motivam o seu ingresso em juízo.

O Supremo se posicionou no sentido de que não há legitimidade recursal conferida ao amicus ao julgar embargo de declaração em face da ação direta de inconstitucionalidade 2.591-ED/DF de Relatoria do Ministro Eros Grau.

Acompanhamos o entendimento de Fredie Didie Jr e do STF de que não há legitimidade recursal do amicus curiae em decisão final de ação declaratória de inconstitucionalidade por ausência de interesse de agir. A decisão de retirar ou manter no ordenamento jurídico vigente a norma objeto da ação é feita em observância ao princípio da Supremacia Constitucional e afeta-a diretamente. Não se pode dizer que a decisão não irá afetar o amicus curiae, pois isso ocorrerá, tanto a ele como a toda a sociedade, como efeito secundário. O efeito primário da decisão é a preservação da harmonia constitucional entre as normas. Pode-se dizer inclusive, que não há interesse recursal por não estar presente o binômio necessidade-utilidade, já que apenas o embargo de declaração está previsto como recurso de mérito para tais decisões.

Não obstante tal posicionamento do STF, ao qual manifestamos concordância, quando a decisão indefere apenas a participação do amicus curiae no processo, não se referindo ao mérito da ação, entendemos ser cabível recurso de apelação desde que feito antes do início do julgamento. O 
Id on Line Revista Multidisciplinar e de Psicoloqia

Id on Line Multidisciplinary Journal and Psycology

amicus comparece ao processo como instrumento de instrução do procedimento, e quando o faz por iniciativa própria deve-se analisar se de fato há elementos que irão interferir nos votos dos Ministros pela própria abertura que o Art. $7^{\circ}, \S 2^{\circ}$ da Lei $9.868 / 99$ traz ao processo. Este tem sido o entendimento do Supremo, conforme nota-se na ADI 3.615/ED, Decisão Monocrática, Rel. Mn. Cármen Lúcia, DJ 17 de março de 2008, e na ADI 3105/ED, Decisão Monocrática, Rel. Mn. Cezar Peluzo, DJ 23 de fevereiro de 2007.

É notório que ao admitirmos que o amicus curiae seja espécie de auxiliar do juízo, e não terceiro interessado estamos vedando sua legitimidade recursal. Isto ocorre haja vista que somente na qualidade de terceiro ele poderá interpor recurso. Como visto, o art. 623 do CPC exige que o terceiro prejudicado demonstre o nexo de interdependência entre o seu interesse de intervir e a relação jurídica submetida à apreciação judicial. Neste caso, não temos nem terceiro interessado nem relação jurídica concreto sendo discutida, uma vez que tratamos de um controle abstrato. Não há como o amicus curiae recorrer, uma vez que não se encaixa nas determinações do caput do art. 623 do CPC, não é nem parte, nem terceiro e nem órgão do Ministério Público.

Ademais, a decisão que declara a constitucionalidade ou inconstitucionalidade do objeto do controle é ex lege irrecorrível, ou seja, é por lei irrecorrível. O art. 26 da Lei 9.868/99 ao tratar das decisões nas ações diretas de inconstitucionalidade e nas ações declaratórias de constitucionalidade determina que a decisão proferida no processo é irrecorrível, cabendo apenas embargo declaratório, não podendo, igualmente, ser objeto de ação rescisória.

Desta forma, embora a presença do amicus curiae, condicionado à aceitação do Ministro Relator, tenha a missão de inspirar caráter pluralista à hermenêutica constitucional, não há legitimidade recursal quanto ao mérito da matéria. Parece-nos correta a posição de negar legitimidade ao amigo da corte, que é a adotada pelo egrégio STF, pois seu interesse processual que é de trazer ao processo matéria com relevante pertinência temática, se encerra quando conclui sua manifestação.

Não há como negar que existem efeitos reflexos na esfera jurídica do amicus curiae quando da decisão proferida nos processos de controle, pois ele também é parte da sociedade que será afetada com a manutenção ou retirada na norma do ordenamento jurídico. Porém, admitir que possa interpor embargo declaratório, que é o único admitido em sede de controle, é admitir que todo e qualquer membro da sociedade possa ingressar também com embargos, por se acharem de forma reflexa ou indireta atingidos pela decisão do Supremo, o que causaria grandes turbulências em nossos Tribunais. Assim, negando-lhe a legitimidade recursal para interpor embargo declaratório, assegura-se de forma indireta a segurança jurídica e estabilidade do arcabouço jurídico brasileiro.

É interessante notar que, embora a jurisprudência tenha reconhecido ao amicus curiae a natureza jurídica de terceiro especial, continua a negar-lhe legitimidade recursal quanto às decisões 
Id on Line Revista Multidisciplinar e de Psicoloqia

Id on Line Multidisciplinary Journal and Psycology

interlocutórias e finais.

No sentido contrário, admitindo a legitimidade recursal, temos os ensinamentos de Binenbojn (2004, p. 104-105), no sentido de reconhecer legitimidade recursal ao amicus, como desdobramento natural de sua atuação. A doutrina citada não é aceita no presente trabalho, pois o amicus curiae traz ao processo elementos para auxiliar a formação da convicção do juiz, porém seus argumentos não vinculam a decisão do magistrado que profere sentença com observância ao princípio da livre motivação das decisões judiciais. Assim não há discussão no tocante a recurso por decisão que contrarie seus argumentos.

Outro ponto que não merece acolhimento da doutrina de Binenbojn (2004, p. 104-105) é o fato de apoiar a legitimidade recursal na possibilidade de perda de "direitos antes reconhecidos pela lei atacada". A decisão que declara a inconstitucionalidade da lei, e por consequência a retira do ordenamento jurídico, tem efeitos ex tunc (retroativos) e erga omnes (eficácia geral). A não ser que haja modulação dos efeitos pelo STF para que tenha efeito ex nunc (não retroativo) ou prospectivos, nos termos do art. 27 da Lei 9868/99, a lei declarada inconstitucional será sempre ato nulo desde sua origem. Segundo Paulo e Alexandrino (2007, p. 791) as decisões de mérito em ação direta de inconstitucionalidade produzem efeitos retroativos (ex tunc), pois fulminam a lei ou ato normativo desde a sua origem. Ou seja, a lei não veio se quer a existir para que pudesse gerar direitos que posteriormente fossem perdidos. Assim o argumento de Binenbojn (2004, p. 104-105), para defesa da legitimidade recursal quanto às decisões de mérito não encontra sustentação na ordem jurídica vigente.

Consolidando a discussão doutrinária a respeito da legitimidade recursal do amici, o novo CPC trouxe a impossibilidade de oposição de recurso pelo amicus curiae em seu art. 138.

Não obstante as disposições do $\S 1^{\circ}$ do Art. 138 do novo CPC, a mesma posição não prevalece quando o foco da discussão é a decisão que indefere sua participação no processo com o fito de trazer novas manifestações. Quando o amicus curiae é quem efetua o pedido de ingresso, sua participação fica condicionada à manifestação do Relator, a quem cumpre apreciar se há relevância da matéria cumulada à representatividade do postulante.

$\mathrm{O}$ art. $7^{\circ}, \S 2^{\circ}$ da Lei 9.868/99 traz que a decisão que admite o ingresso no amicus curiae no processo é feita por despacho irrecorrível. Ao falar em despacho irrecorrível, o art. $7^{\circ}, \S 2^{\circ}$ não se refere à simples decisão interlocutória, e sim a decisões de cunho positivo. Isto é, a decisão que defere o ingresso no amicus curiae no processo é que é dotada de irrecorribilidade.

Já a decisão denegatória não é tratada pelo diploma. Binenbojn (2004, p.103), em seu artigo $A$ Dimensão do Amicus Curiae no Processo Constitucional Brasileiro: Requisitos, Poderes Processuais E Aplicabilidade No Âmbito Estadual nos ensina que "as decisões de conteúdo negativo indeferitórias do ingresso formal do amicus - podem, à evidência, ser impugnadas pelo interessado 
Id on Line Revista Multidisciplinar e de Psicoloqia

Id on Line Multidisciplinary Journal and Psycology

através do recurso cabível de agravo regimental". E sustenta seu argumento com base na interpretação hermenêutica restritiva, sendo que à "exceção da regra geral da recorribilidade, a irrecorribilidade deve ser interpretada restritivamente para alcançar apenas as decisões de conteúdo positivo" (BINENBOJN, 2004).

Outro argumento do qual se utiliza Binenbojn (2004) é de que as decisões denegatórias do ingresso do amicus curiae causam agravo específico ao postulante. Desta forma, existindo agravo específico ao postulante, em seu suposto direito, há que ser reconhecido ao postulante o direito de obter o pronunciamento do colegiado a respeito de sua postulação. $O$ último argumento em que firma seu posicionamento é de que, baseado em uma filtragem constitucional do texto do art. $7^{\circ}, \S 2^{\circ}$, devese ter interpretação que prestigie o direito ao contraditório e à ampla defesa, bem como a garantia do devido processo legal, dando a inteligência mais benéfica aos postulantes, permitindo que, por meio de agravo regimental, submetam a decisão indeferitória do relator ao Plenário da Corte.

O ingresso do amicus curiae, no processo de controle não pode ficar sujeito a simples juízo de oportunidade exercitado com exclusividade do magistrado. Assim, conforme Bueno (2008, p. 201), em função dos conceitos vagos que norteiam a qualificação do amicus curiae como representante adequado, não se pode caracterizar a decisão que indefere ou admite sua participação no processo como incontrastável, devendo esta tecer considerações objetivas com as razões pelas quais defere ou indefere sua intervenção, e será recorrível para que o colegiado, como um todo, possa manifestar-se acerca de seu acerto ou desacerto.

Em relação à recorribilidade das decisões que indeferem o ingresso do amicus curiae no processo, entendemos ser possível. Nos casos em que o motivo do indeferimento seja a representatividade do postulante, o entendimento é de que haverá agravo ao postulante.

\section{Conclusão}

A figura do amicus curiae, por ser recente na doutrina pátria, positivado inicialmente na Lei 6.835/76, de 07/12/1976, tem a função de levar a conhecimento do magistrado noções técnicas pertinentes a matéria discutida, em relação a qual deve ter vasta e notória experiência. Recentemente, o instituto foi positivado no novo Código de Processo Civil.

Demonstramos a existência de três correntes doutrinárias e os alicerces de seus argumentos. A primeira corrente defende o amicus como assistente qualificado, que é espécie de intervenção de terceiros ad coadjuvandum, nos ensinamentos de Didier (2006, p. 301). A segunda corrente traz a figura processual como terceiro interveniente, defendo que há interesse no resultado do conflito. Já a 
Id on Line Revista Multidisciplinar e de Psicoloqia

Id on Line Multidisciplinary Journal and Psycology

terceira corrente traz o amicus como auxiliar do juízo.

Não obstante a topologia dada ao amicus no novo CPC, manifestamos concordância quanto à posição da terceira corrente, apoiada pelo processualista Fredie Didier, trazendo o amicus curiae como auxiliar do juízo, haja vista que suas considerações permitiram ao magistrado o peso que a sua convicção determinar. Cumpre informar que corroborando o posicionamento de Didier é de se notar que é prescindível ao amicus curiae a demonstração do interesse processual, devendo demonstrar apenas interesse institucional consubstanciado no seu vasto conhecimento técnico acerca da matéria discutida em juízo. Outro ponto favorável à posição de Didier, e contrário a primeira corrente, é o fato de o assistente ser espécie de intervenção de terceiros ad coadjunvandum.

Embora não seja questão pacífica, a primeira turma do Supremo Tribunal Federal já manifestou entendimento de que o amicus é singular assistente.

O cerne do tema proposto é analisar os poderes do amicus curiae nos processos de controle de constitucionalidade. O controle abstrato, possível apenas nas constituições rígidas, embora vede a participação de terceiros em tais processos, permite a oitiva de pessoas com experiência no tema debatido, sugerindo a incorporação de ciências sociais e de métodos de interpretação voltados ao atendimento do interesse público.

São dois os requisitos para ingresso do amicus curiae nas ações de controle de inconstitucionalidade: relevância da matéria e representatividade do postulante. O momento para ingresso no processo se dá entre a propositura da ação e sua inclusão em pauta para julgamento, quando o processo já estaria maduro para debates. Sua admissão deverá ser analisada pelo relator do processo, que verificará o preenchimento dos requisitos e conveniência e oportunidade da manifestação.

Deferida sua participação no processo, o amicus terá como prerrogativas processuais a manifestação escrita e oral, e interposição de recurso contra decisão que nega seu ingresso no processo.

Quanto à legitimidade para opor recursos entendemos que, sendo este instrumento adequado para impugnar decisão e provocar o reexame da mesma com o fim de alcançar sua reforma, anulação ou integração, e não prescinde da demonstração de legitimidade e interesse recursal. Neste ponto, só há interesse recursal e legitimidade conferidos ao amicus curiae no tocante a decisão que nega seu ingresso no processo. O amicus ingresso no processo como pessoa experiente, ou com autoridade na matéria em caso de necessidade de esclarecimentos de circunstâncias de fato, ou de notória insuficiência de informações existentes nos autos.

Desta forma, se houve permissão de que ingressasse no processo, fizesse constar sua manifestação, já cumpriu sua função e exauriu seu interesse institucional no processo, que é de levar 
Id on Line Revista Multidisciplinar e de Psicoloqia

Id on Line Multidisciplinary Journal and Psycology

ao conhecimento do magistrado conhecimentos técnicos. Cumprida sua função, esgota-se sua manifestação no processo. Por ser estranho à relação processual, não demonstra interesse em sua reforma. Embora a questão encontre-se apequenada por somente ser possível impetrar embargos de declaração, o óbice à postulação de recurso do amicus curiae diminuiu os legitimados e, por conseguinte, acelera o trâmite das ações. Ao admitirmos o amicus com auxiliar do processo estamos, via reflexa, negando sua legitimidade recursal, pois somente na qualidade de terceiro poderia interpor recurso.

Outra é a posição adotada quanto à decisão objeto de recurso nega o ingresso do amicus curiae ao processo baseada no não cumprimento dos requisitos previstos na Lei 9868/1999. Neste caso, caberá recurso de apelação, desde que interposto antes do início do julgamento, devendo analisar se há fatos ou elementos que interferirão nos votos dos Ministros. Há que se notar que as decisões que negam o ingresso do postulante causam agravo a ele próprio por atingirem sua imagem e gera legitimidade recursal, em atendimento as garantias constitucionais do contraditório e ampla defesa.

\section{Referências}

BINENBOJM, Gustavo. A DIMENSÃO DO AMICUS CURIAE NO PROCESSO CONSTITUCIONAL BRASILEIRO: Requisitos, poderes processuais e aplicabilidade no âmbito estadual. Revista Eletrônica de Direito do Estado, Salvador, Instituto de Direito Público da Bahia, $\mathrm{n}^{\mathrm{o}}$ 1, janeiro de 2004, disponível em $\langle\underline{\mathrm{http}} / / / \mathrm{www}$.direitodoestado.com.br $>$. Acesso em 25/02/2016.

BISCH, Isabel da Cunha. O Amicus Curiae, As Tradições Jurídicas e Controle Constitucional. Porto Alegre, Ed. Livraria do Advogado, 2010.

BONAVIDES, Paulo. Curso de Direito Constitucional. São Paulo, Ed. Malheiros. 2007.

BRASIL. Constituição da República Federativa do Brasil de 05 de outubro de1988.Disponívelem: $<$ http://www.planalto.gov.br/ccivil 03/constituicao/ConstituicaoCompilado.ht m> Acesso em: 20/02/2016.

BRASIL. Lei 9.868, de 10 de novembro de 1999. Dispõe sobre o processo e julgamento da ação direta de inconstitucionalidade e da ação declaratória de constitucionalidade perante o Supremo Tribunal Federal. Disponível em: http://www.planalto.gov.br/ccivil_03/leis/L9868.htm . Acesso em: $15 / 01 / 2016$.

BRASIL. Lei 9.882, de 03 de dezembro de 1999. Dispõe sobre o processo e julgamento da arguição de descumprimento de preceito fundamental, nos termos do $\$ 1^{\circ}$ do artigo 102 da Constituição Federal. Disponível em: < http://www.planalto.gov.br/ccivil_03/leis/19882.htm >. Acesso em 10/02/2016.

BRASIL. Lei 6.835, de 07 de dezembro de 1976. Dispõe sobre a Comissão de Valores Mobiliários. Disponível em < http://www.planalto.gov.br/ccivil 03/leis/L6385.htm>. Acesso em: 05/03/2016. 
Id on Line Revista Multidisciplinar e de Psicologia

Id on Line Multidisciplinary Journal and Psycology

BRASIL. Lei 13.105, de 16 de março de 2015. Institui o Código de Processo Civil. Disponível em: http://www.planalto.gov.br/ccivil 03/ ato2015-2018/2015/lei/113105.htm. Acesso em: 14/04/2016. BRASIL. Supremo Tribunal Federal (STF). Regimento interno atual, atualizado até janeirode2015.Disponívelem: $<$ http://www.stf.jus.br/arquivo/cms/legislacaoRegimentoInterno/anexo/ RISTF.pdf $>$. Acesso em: 04/01/2016.

BRASIL. Supremo Tribunal Federal (STF). Regimento interno de 27 de outubro de 1980.Disponívelem: $<$ http://www.stf.jus.br/ARQUIVO/NORMA/REGIMENTOINTERNO1980.PDF> Acesso em: 01/02/2016.

BRASIL. Supremo Tribunal Federal (STF). Ação Direta de Inconstitucionalidade (ADI) $\mathbf{n}^{\mathbf{o}}$ 2.238/DF. Relator Ministro Ilmar Galvão. Tribunal Pleno. Data de julgamento: 27/08/2001. Data da Publicação: 31/08/2001.

BRASIL. Supremo Tribunal Federal (STF). Ação Direta de Inconstitucionalidade (ADI) no 3.615ED/PB. Relatora Ministra Carmem Lúcia. Data de Julgamento:17/03/2008. Tribunal Pleno. Data da Publicação: 25/04/2018.

BRASIL. Supremo Tribunal Federal (STF). Ação Direta de Inconstitucionalidade (ADI) $\mathbf{n}^{\mathbf{0}}$ 3105ED. Relator Ministro Cezar Peluso. Data de Julgamento: 02/02/2007. Tribunal Pleno. Data da Publicação: 23/02/2007.

BRASIL. Supremo Tribunal Federal (STF). Ação Direta de Inconstitucionalidade (ADI) $\mathbf{n}^{\mathbf{o}}$ 1.350/RO. Relator Ministro Celso de Mello. Data de Julgamento: 24/02/2005. Tribunal Pleno. Data da Publicação: 01/12/2006.

BRASIL. Supremo Tribunal Federal (STF). Ação Direta de Inconstitucionalidade (ADI) $\mathbf{n}^{\mathbf{o}}$ 2.937/DF. Relator Ministro Cezar Peluso. Data de Julgamento: 23/02/2012. Tribunal Pleno. Data da Publicação: 29/05/2012.

BRASIL. Supremo Tribunal Federal (STF). Ação Direta de Inconstitucionalidade (ADI) $\mathbf{n}^{\mathbf{o}}$ 3.889/RO. Relator Ministro Joaquim Barbosa. Data de Julgamento: 29/10/2007. Tribunal Pleno. Data da Publicação: 06/11/2007.

BRASIL. Supremo Tribunal Federal (STF). Ação Direta de Inconstitucionalidade (ADI) $\mathbf{n}^{\mathbf{o}}$ 2.777/SP. Relator Cesar Peluso. Data de Julgamento: 07/10/2003. Tribunal Pleno. Data da Publicação: $16 / 10 / 2003$.

BRASIL. Supremo Tribunal Federal (STF). Ação Direta de Inconstitucionalidade (ADI) $\mathbf{n}^{\mathbf{0}}$ 4.140/GO. Relatora Ministra Ellen Gracie. Data de Julgamento: 25/05/2009. Tribunal Pleno. Data da Publicação: 29/05/2009.

BRASIL. Supremo Tribunal Federal (STF). Ação Direta de Inconstitucionalidade (ADI) no 2.591ED/DF. Relator Ministro Eros Grau. Data de Julgamento: 14/12/2006. Tribunal Pleno. Data da Publicação: 13/04/2007.

BRASIL. Superior Tribunal de Justiça (STJ). Resp n $\mathbf{n}^{\mathbf{6}}$ 677.585/RS. Relator Ministro Luiz Fux. Data de Julgamento: 06/12/2005. Primeira Turma. Data da Publicação: 13/02/2006. 
BRASIL. Supremo Tribunal Federal (STF). Arguição de descumprimento de preceito fundamental (ADPF) no 46/DF. Relator Ministro Marco Aurélio. Data de julgamento: 05/08/2009. Tribunal Pleno. Data da Publicação: 26/02/2010.

BUENO, Cássio Scarpinela. Amicus Curiae no Processo Civil Brasileiro. São Paulo, Ed. Saraiva, 2008.

DIDIER JÚNIOR, Fredie. Direito Processual Civil. Salvador, Editora Jus Podivm, 2006. V. 1.

LENZA, Pedro. Direito Constitucional Esquematizado. São Paulo, Ed. Saraiva, 2009.

MELO, Adriana Zawada. et al. Constituição Federal Interpretada: Artigo por artigo, parágrafo por parágrafo. São Paulo, Ed. Manole, 2010.

MORAES, Diogo Souza. As correntes doutrinárias sobre a natureza jurídica do "amicus curiae". Jus Navigandi, Teresina, ano 16, n. 2746, 7.jan.2011. Disponível em: Acesso em: 07/03/2016.

NEVES, Daniel Amorim Assumpção. Manual de Direito Processual Civil. Volume Único. São

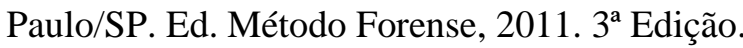

\section{Como citar este artigo (Formato ABNT):}

Amicus curiae

GINO, B.S.B.; SILVA, E.S.S.F.; DANTAS, T.C.C.P. Legitimidade Recursal do Amicus Curiae. Id on Line Revista de Psicologia, Julho de 2016, vol.10, n.30, Supl 3. p. 124 - 142 . ISSN 1981-1179.

Recebido: 10/07/2016

Aceito:12/07/2016 